\title{
HYDROGRAPH ANALYSIS FOR SUSTAINABLE KARST AQUIFER PROTECTION AND MANAGEMENT
}

\author{
Oleh: \\ Hendy Fatchurohman, Ahmad Cahyadi, Slamet Suprayogi \\ Department of Environmental Geography, Geography Faculty, Universitas Gadjah Mada \\ ahmadcahyadi@geo.ugm.ac.id
}

\begin{abstract}
Abstrak
Keberadaan mata air karst sangat penting karena dapat berfungsi sebagai sumber air minum. Analisis hidrograf mataair karst merupakan langkah mendasar untuk menilai dan mengetahui kondisi daerah tangkapan air di daerah karst. Kurva resesi dipahami sebagai bagian paling stabil di hidrograf banjir tunggal yang mewakili karakteristik akuifer. Oleh karena itu, analisis kurva resesi digunakan untuk menentukan karakteristik akuifer, termasuk tingkat karstifikasi. Makalah ini difokuskan pada bagaimana menentukan derajat karstifikasi. derajat karstifikasi yang digunakan dalam makalah ini diperkenalkan oleh Malik (2007) yang juga memperhatikan analisis kurva resesi. Metode ini difokuskan pada karakteristik independen sub-rezim pada periode resesi. Kurva resesi adalah masukan utama untuk membuat persamaan recessional yang dikonversi menjadi nilai derajat karstifikasi. Skala kualitatif mulai dari 1 sampai 10 mewakili tingkat karstifikasi. Kedua metode tersebut berlaku umum di Indonesia.
\end{abstract}

Kata kunci: Airtanah, derajat karstifikasi, hidrograf, manajemen

\begin{abstract}
The existence of karst springs is very essential due to their function as drinking water source. An analysis of Karst spring hydrograph is very fundamental step to asses and determine the condition of the catchment area in karst terrain. Recession curve is believed to be the most stable part in single flood hydrograph that represents the aquifer characteristics. Therefore, recession curves analysis has been used to determine the aquifer characteristics, including the degree of karstification. This paper focuses on how to determine the karstification degree. The karstification degree determination used in this paper was introduced by Malik (2007) that also concerned on recession curve analysis. This method focuses on the characteristics of independent sub-regimes in the recession periods. Recession curve is the main input to create recessional equations which are converted into karstification degree values. A qualitative scale ranging from 1 to 10 represent the degree of karstification. These two methods are generally applicable in Indonesia.
\end{abstract}

Keywords: Groundwater, degree of karstification, hydrograph, management

\section{INTRODUCTION}

Water resources is one of the major issues all over the world and facing problems concerning the quantity and quality. In 2015 it is estimated that 663 million people worldwide still use unimproved water sources, for instance unprotected wells, surface waters and springs (UNICEF \& WHO, 2015). The global distribution of water circulating the Earth varies in different forms and place. After excluding the volumes represented by the oceans and polar ice, the 
most widely distributed and significant water resource on Earth is groundwater. Groundwater and surface water are the most water reservoirs utilized by humans because of their accessibility (Walton, 1970; Fitts, 2002; Todd \& Mays, Groundwater Hydrology-Third Edition, 2005; Younger, 2007).

Karst is an international terminology used to describe a distinctive landscape characterized by extensive subterranean drainage, caves, and closed depressions. Karst terrain is particularly developed in soluble rock such as carbonate rocks, evaporates, and quartzite (Bögli, 1980; Gillieson, 1996; Ford \& Williams, 2007). About 20-25\% of the world's population depends on karst water resources. Most of the biggest springs in the world are located in karst area. Therefore, karst aquifers play an important role for human water supply and one of the most significant aquifer formations along with alluvium (Bakalowicz, 2005; Ford \& Williams, 2007)

Over the time, groundwater resources have not been well managed including karst aquifers. Karst aquifers formed in a very complex hydrological system. Developed in fracture media and soluble rocks have led karst aquifers into various porosity types and aquifer properties. Most commonly, karst aquifers contain three different porosity types, which are diffuse, fissure and conduit. The recharge area of karst aquifer is one of the most necessary components to be considered. Recharge area of karst aquifer possibly includes karstic and non-karstic portions with the combination of autogenic and allogenic inputs (Gillieson, 1996).

Karst aquifer receives, stores, and transmits more water compared to all surface streams. Karst springs is one of the most important surface water source in karst area. Karst springs is also known as the world's largest springs with the highest discharge rates compared to springs from other aquifer types. Among the largest in the world, karst springs ensure that their importance for water supplies is widespread (Kresic, 2013).

Karst spring hydrograph is an essential element for water resource management. The form of karst spring hydrograph reflects the aquifer characteristics. The shapes of flood discharge hydrographs represent aquifer responses to recharge and contain information about the interior condition of karst drainage basin. Hydrograph is generally more stable during the recession period and represents hydraulic and geometrical characteristics of the aquifers (Fiorillo, 2014). Besides, recession curve of karst spring hydrograph describes the significant progress when the maximum discharge recorded until the next consecutive pulse. Each part of the single flood hydrograph curve will represent the contribution of different porosity types (Civita, 2008). Karst spring hydrographs analysis especially focused on recession curve data possibly provides valuable information in order to identify some characteristics of the karst aquifer and water resources management (Bonacci, 1993; Ford \& Williams, 2007; White, 1988).

Recession curve analysis provides useful information to interpret the hydrological significance and characterize specific parameters of the springs. The main advantage of analyzing spring recession curves is that the drainage mechanisms in the aquifer and its quantitative parameters will be able to be estimated (Amit, et al., 2002; Malik \& Vojtkova, 2012). Recession curve analysis plays an important role in determining the geological and storage characteristics of the karst aquifer. However, the rising limb of the hydrograph must have been analyzed to determine the karstification degree of the aquifer (Rashed, 2012). Karstification degree is very useful in the application of karst river basin management and deciding 
protection zone for karst aquifer. Groundwater management and protection zone in karstic aquifer can be based on determination of karstification degree.

Recession curve analysis also provide information regarding of flow components. From recession curve analysis, the percentage of baseflow, interflow and conduit flow that supply the total flow can be determined (Fatchurohman and Adji, 2014). Furthermore, Widyastuti (2014) stated that the presence of sinkholes with small catchment areas lead to high concentration of flow that sinks into groundwater systems. The existence of sikholes are also indicate the development of karstification degree in a karst area. Therefore, determination of karstification degree in Gunung Sewu karst area is important in order to formulate management action, restoration, and conservation.

Based on those issues, this paper focused on introducing spring hydrograph analysis to provide general information of the aquifer systems in karst drainage basin within Gunung Sewu karst area. The objectives of this paper were to provide technical procedures determining the characteristics of recession curves and karstification degree. This paper is a literature review, considering that recession curve analysis is a very minor methodology that are used among hydrologist in Indonesia. Therefore, it is necessary to provide step by step procedure constructing Master Recession Curve (MRC) and its application for drainage basin management.

\section{METHOD}

The method that used in this paper was literature review. Beside literature review for recession analysis, this paper also describes the procedure of data collecting and processing. The main material of recession analysis is hydrograph series data that obtained from automatic water level logger installation. Onset $\mathrm{HOBO}$ Water level data logger kits required for annual water level observation. The $\mathrm{HOBO}$ water level data logger sensor measure the water pressure with operation range from 0 to $400 \mathrm{kPa}(0$ to $58 \mathrm{psi}$ ); approximately 0 to $30.6 \mathrm{~m}$ ( 0 to $100 \mathrm{ft}$ ) of water depth at sea level, or 0 to $33.6 \mathrm{~m}(0$ to $111 \mathrm{ft})$ of water at $3,000 \mathrm{~m}(10,000 \mathrm{ft})$ of altitude. Water level measurement accuracy up to $1,5 \mathrm{~cm}$ with $-0.05 \%$ typical error. HOBOware Pro software provides easy conversion to accurate water level reading, fully compensated for barometric pressure, temperature, and water density (use barometric pressure data from nearby weather station). After automatic water level data logger installed, several steps required as follows:

The challenge of applying discharge measurements in karst are significantly greater although the principles are the same as in any other hydrologic setting. In any case, three general methods can be applied to both surface and subsurface streams in karst channels i.e.: a) weirs and flumes, b) area velocity, and c) dye tracers (Kresic, 2013). The area velocity method in this case surface floats is particularly useful during a flood when the conditions are dangerous to deploy other measurement procedures (Hiscock, 2005). Surface floats method require enough upstream to gain enough ambient velocity before entering the reach. The water velocity can be calculated by measuring the distance of the reach and the time required for the float to travel between the reach. This procedure repeated several times to obtain average surface velocity. 
After several discharge data obtained from numerous measurements, stage discharge rating curve (Fig. 1) generated to determine linear regression between water level and stream discharge. After stage discharge rating curve generated, the regression function used to convert the measured water level data into hydrograph series data. Combined with barometric pressure, recorded water level data will be smoothen and then converted to hydrograph data series using regression function from stage discharge rating curve.

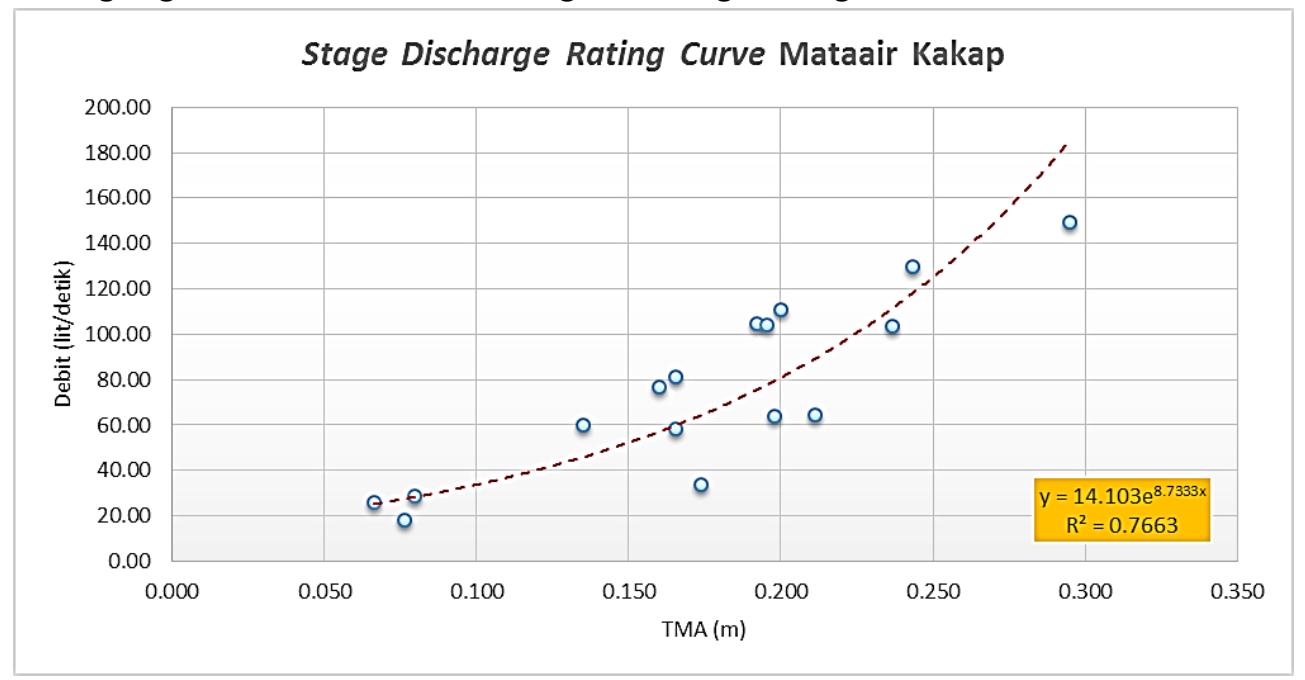

Figure 1. An Example of Stage Discharge Rating Curve

\section{RESULT AND DISCUSSION}

Recession curve is the representation of discharge depletion during periods with minimum or no precipitation (Tallaksen, 1995). In recession period, hydrograph is generally more stable and its shape represents hydraulic and geometrical characteristics of the aquifer. Recession curve of karst spring hydrograph also describes significant progress where the maximum discharge recorded until the next consecutive pulse.

In this chapter, technical procedure calculating the karstification degree explained step by step. The next step after hydrograph series created is master recession curve (MRC) construction. Master recession curve is a graph that express the average or main recession curve shape that assembled from several recession periods in a particular site. Master Recession Curve (MRC) commonly used to describe and analyze the average recession from a set of hydrograph recessions (Rivera-Ramírez, et al., 2002; Posavec, et al., 2010).

MRC construction is necessary to characterize recession behavior in each karst spring. MRC is also the main input to determine the karstification degree. MRC construction can be done by assembling several recession curves using semiautomatic tool called RC 4.0. Numerous theoretical considerations already included in this tool that provide accurate modeling to construct MRC. RC 4.0 tool is included in HydroOffice software which is open source and free access. This software provide several tools for hydrological modeling such as baseflow separation, MRC construction, discharge regime separation, piper plot, etc.

Numerous methods have been developed to construct the MRC. Graphical method is a traditional way to construct MRC, and the most common way are matching strip (Fig. 2) and correlation method (Fig 3.). Another traditional method that commonly used is tabulating 
method. In this method, the recession period is tabulated, shifted and then the average discharges are calculated for each time step in the period. (Tallaksen, 1995).
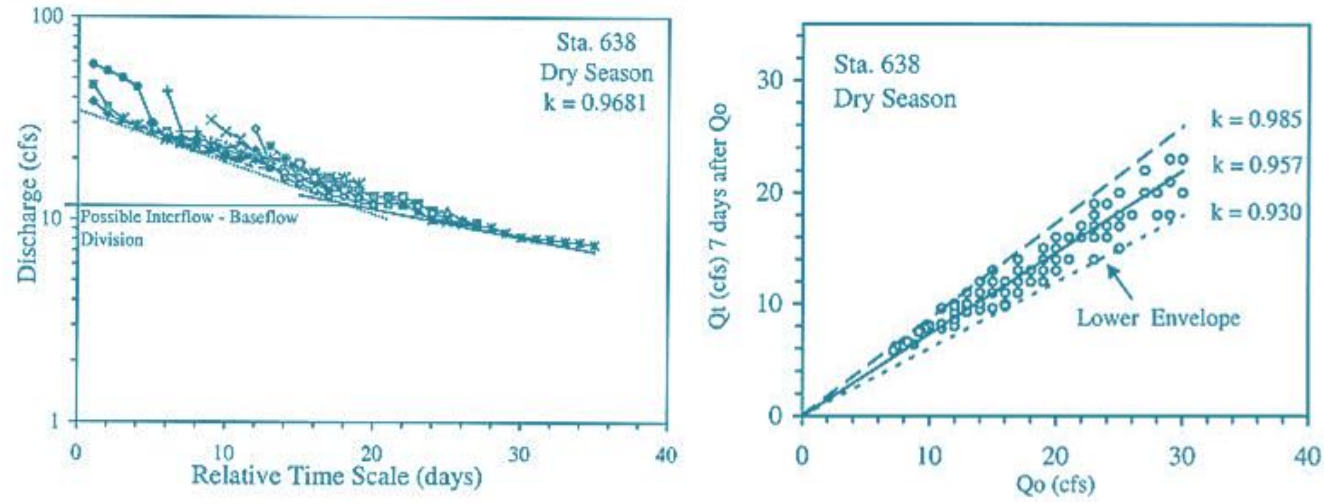

Figure 2. An example of MRC construction using matching strip and correlation method.

(Rivera-Ramírez, et al., 2002)

\section{Determining Karst Discharge Regime}

The term regime is defined as changing conditions of groundwater phenomenon, characterized by regular pattern of occurrence. As it described in Equation 8, Boussinesq (1877) and Maillet (1905) obtained an approximate analytical solution for recession curve analysis described by exponential equation:

$$
Q_{t}=Q_{0} e^{-\alpha t}
$$

$Q_{0}$ is the initial discharge, $Q_{t}$ is the discharge at time $t$ and $\alpha$ is the recession coefficient-an intrinsic aquifer parameter, expressed in reciprocal time units $\left(\right.$ day $^{-1)}$ or $\left(\mathrm{s}^{-1}\right)$.

Finding single equation that able to entirely describe recession hydrograph is difficult due to the participation of various flow components (sub regimes) in the process of discharge recession (Malik, 2015). Therefore, the sum of several exponential segments of the total recession functions is required to interpret the entire recession hydrograph. Later Study by Kullman (1990) in Malik (2015) ; Bonacci (1993); Tallaksen (1995) described that more than two flow components presence in karst spring hydrograph. Other descriptions of recession curve that describes each flow component is also necessary to be considered.

$$
Q_{t}=\sum_{i=1}^{n} Q_{0} e^{-\alpha t}
$$

$$
Q_{t}=\sum_{i=1}^{n} Q_{0} e^{-\alpha t}+\sum_{j=1}^{m}\left(\frac{1}{2}+\frac{|1-\beta j t|}{2(1-\beta i t)}\right) Q_{0 j}=Q_{0}(1-\beta \mathrm{jt})
$$


Where every ith or $j$ th member of Eq. 1 and 2 describes one flow component, as it shown in Figure 3 Kullman (1990) in Malik (2015) proposed a linear model for turbulent flow in conduits, analogous to discharge recession in open surface channels (Eq. 11), where $\beta$ is the recession coefficient for quick flow or conduit flow.

$$
Q_{t}=\left(\frac{1}{2}+\frac{|1-\beta j t|}{2(1-\beta i t)}\right) Q_{0}\left(1-\beta_{t}\right)
$$

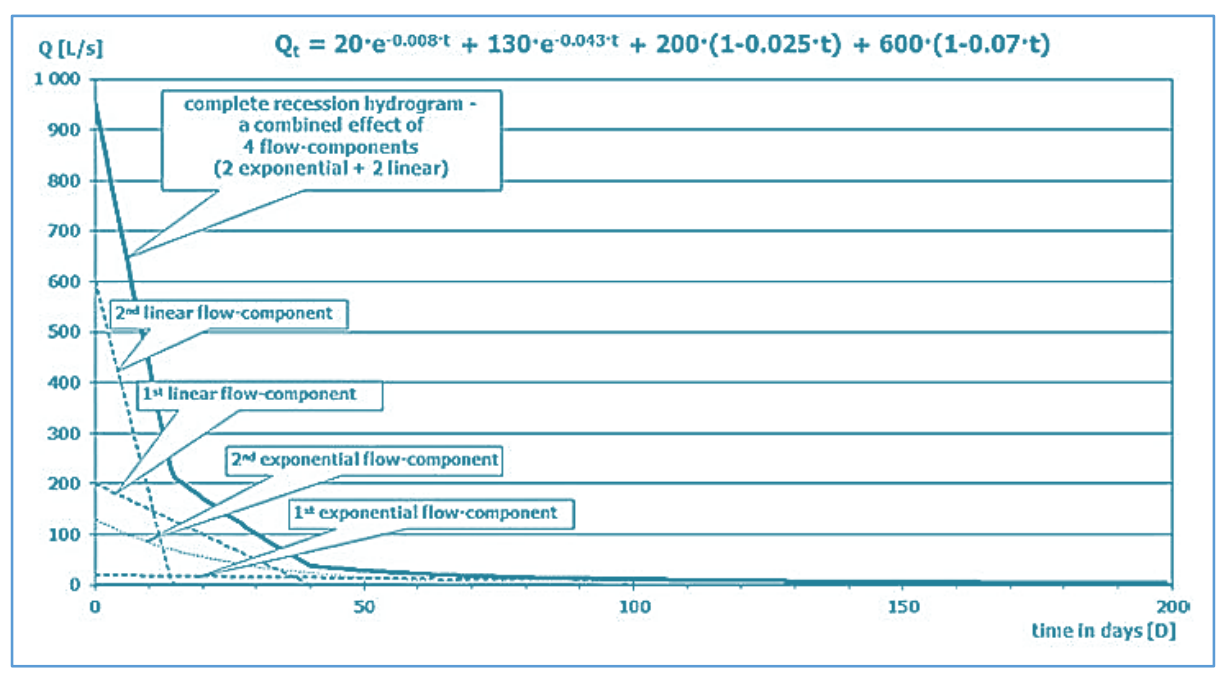

Figure 3. Four flow components in ideal recession hydrograph (master recession curve)normal plot (Malik, 2015).

\section{Calculating the Karstification Degree}

According to Malik (2012) karstification degree can be classified using a 10-degree scale, from the 1st degree for the lowest karstification, and 10th degree for best developed karstic behavior. The number of flow sub-regimes that presence in MRC used as the main consideration in determining the karstification degree. Typical recessional equations used to describe recessional types that characterized by the existence of different flow sub-regimes (Table 1).

Constructing MRC is necessary in order to combine several individual recessions to provide an average characterization of baseflow response. Description of recession process by one (master) recession curve as a representative can be done by assembling numerous sets of individual recessional discharge successions into the new shape which is the most probable unaffected discharge recession The construction of MRC try to solved time variability problem in recessions as a mean curve. (Tallaksen, 1995;Nathan \& McMahon, 1990; Malik \& Vojtkova, 2012). 
Table 1. Karstification degree in recharge areas of springs according to recession curves parameters

\begin{tabular}{|c|c|c|c|}
\hline $\begin{array}{l}\text { Karstifi } \\
\text { cation } \\
\text { Degree }\end{array}$ & $\begin{array}{l}\text { Groundwater flow } \\
\text { sub-regimes type }\end{array}$ & $\begin{array}{l}\text { Characteristic } \\
\text { recession curve } \\
\text { equation }\end{array}$ & $\begin{array}{l}\text { Characteristics of } \\
\text { recession-curve } \\
\text { parameters }\end{array}$ \\
\hline $\begin{array}{l}0.5 \\
1.0\end{array}$ & Single laminar sub-regime, lower values of $\alpha 1$ & $Q_{t}=Q_{01} e^{-\alpha 1 t}$ & $\begin{array}{l}\alpha_{1}<0.001 \\
\alpha_{1}=0.001-0.0025\end{array}$ \\
\hline 2.0 & Single laminar sub-regime, higher values & & $\begin{array}{l}\alpha_{1}=0.0025-0.007 \\
\alpha_{1}>0.007\end{array}$ \\
\hline
\end{tabular}

\section{3}

\section{5}

2.7

regimes with merely laminar flow characterized by

$\mathrm{Q}_{\mathrm{t}}=\mathrm{Q}_{01} \mathrm{e}^{-\alpha 1 \mathrm{t}}+$
$\mathrm{Q}_{02 \mathrm{e}^{-\alpha 2 \mathrm{t}}}$

$\alpha_{1}<0.0024$ and

$\alpha_{2}<0.033$

$\alpha_{1}<0.0024$ or

$\alpha_{2}<0.033$

$\alpha_{1}=0.0024-0.0045$

$\alpha_{2}=0.033-0.067$

$\alpha_{1}=0.0024-0.0043$, and $\alpha_{2}=$

0.060-0.16

$\alpha_{1}>0.0043$ and $\alpha_{2}<0.060$

$\alpha_{1}=0.0041-0.018$ and $\alpha_{2}=$ $0.055-0.16$

\begin{tabular}{lll}
4.0 & & \\
\hline 4.3 & $\begin{array}{l}\text { Discharge hydrogram is composed of a sub-regime with } \\
\text { turbulent flow and a sub-regime with laminar flow. }\end{array}$ & $Q_{t}=Q_{01} e^{-\alpha 1 t}+Q_{04}$ \\
$\left(1-\beta_{1} t\right)$
\end{tabular}

4.7

$\alpha_{1}>0.018$ or $\alpha_{2}>0.16$

$\alpha_{1}>0.018$ and $\alpha_{2}>0.16$

low values of $\beta$ and $\alpha$

\begin{tabular}{|c|c|c|c|}
\hline 5.5 & $\begin{array}{l}\text { Complex discharge regime, a combination of one sub- } \\
\text { regime with turbulent flow and two sub-regimes with } \\
\text { laminar groundwater flow.. }\end{array}$ & $\begin{array}{l}Q_{t}=Q_{o 1} e^{-\alpha 1 t}+ \\
Q_{o 2} e^{-\alpha 2 t}+Q_{04}(1- \\
\left.\beta_{1} t\right)\end{array}$ & $\alpha_{1}>0$ and $\alpha_{2}>0$ and $\beta_{1}>0$ \\
\hline 6.0 & $\begin{array}{l}\text { Very complex discharge regime, a combination of two } \\
\text { sub-regimes with turbulent flow and two sub-regimes } \\
\text { with laminar groundwater flow. }\end{array}$ & $\begin{array}{l}Q_{t}=Q_{01} e^{-\alpha 1 t}+ \\
Q_{02} e^{-\alpha 2 t}+Q_{04}(1- \\
\left.\beta_{1} t\right)+Q_{05}\left(1-\beta_{2} t\right)\end{array}$ & $\beta_{1}, \beta_{2}$, and $\alpha_{1}, \alpha_{2}$ high values \\
\hline 7.0 & $\begin{array}{l}\text { Discharge regime is a combination of one sub-regime } \\
\text { with laminar flow with two to three sub-regimes with } \\
\text { turbulent flow. Substantial role in groundwater } \\
\text { discharge plays the subregime with laminar flow }\end{array}$ & \multirow[t]{2}{*}{$\begin{array}{l}Q_{t}=Q_{01} e^{-\alpha 1 t}+ \\
Q_{02} e^{-\alpha 2 t}+Q_{04}(1- \\
\left.\beta_{1} t\right)+Q_{05}\left(1-\beta_{2} t\right)+ \\
Q_{06}\left(1-\beta_{3} t\right)\end{array}$} & $\begin{array}{l}\text { Nilai } \beta_{3}, \beta_{2}, \beta_{1} \text { and } \alpha \text { high } \\
\text { values, } \beta_{1}>\beta_{2}\end{array}$ \\
\hline 8.0 & $\begin{array}{l}\text { Discharge regime is a combination of a sub-regime with } \\
\text { laminar flow with two to three sub-regimes with } \\
\text { turbulent flow. }\end{array}$ & & $\beta_{3}, \beta_{2}, \beta_{1}$ and $\alpha$ thigh values \\
\hline 8.5 & $\begin{array}{l}\text { Groundwater flow regime is represented merely by } \\
\text { turbulent flow, with only one turbulent flow sub-regime } \\
\text { present, which represents turbulent circulation in channel } \\
\text { systems (conduits) without hydraulic connection to the } \\
\text { groundwater in adjacent rock blocks. Groundwater } \\
\text { circulation is mostly connected to vadose zone }\end{array}$ & $Q_{t}=Q_{04}\left(1-\beta_{1} t\right)$ & $\alpha_{1} ; \alpha_{2}=0$ and $\beta_{1}>0$ \\
\hline 9.0 & $\begin{array}{l}\text { Groundwater flow regime is represented merely by } \\
\text { turbulent flow, consisting of two turbulent flow sub- } \\
\text { regimes. These represent turbulent circulation in channel } \\
\text { systems (conduits) without hydraulic connection to the } \\
\text { groundwater in adjacent rock blocks Groundwater } \\
\text { circulation is mostly connected to vadose zone }\end{array}$ & $\begin{array}{l}\mathrm{Q}_{\mathrm{t}}=\mathrm{Q}_{04}\left(1-\beta_{1} \mathrm{t}\right)+ \\
\mathrm{Q}_{05}\left(1-\beta_{2} \mathrm{t}\right)\end{array}$ & $\beta_{1}$ dan $\beta_{2}$ low values \\
\hline 10.0 & $\begin{array}{l}\text { Complex turbulent flow regime of } \\
\text { groundwater discharge, consisting of three different } \\
\text { turbulent flow subregimes. Probability of a very } \\
\text { complex groundwater circulation by occasional flows in } \\
\text { the vadose zone. Documented only in perennial flows. }\end{array}$ & $\begin{array}{l}Q_{t}=Q_{04}\left(1-\beta_{1} t\right)+ \\
Q_{05}\left(1-\beta_{2} t\right)+Q_{06} \\
\left(1-\beta_{3} t\right)\end{array}$ & $\beta_{1}, \beta_{2}$ dan $\beta_{3}$ thigh values \\
\hline
\end{tabular}

Source : Malik (2007\&2012) 
MRC main advantage is its ability to easily identified flow regimes. Identification of flow regimes from MRC is more reliable than from combined single recession curves. The determination of karstification degree from flow regimes identification is useful as scientific adjustment before formulating management actions in karst area. Karst flow components separation in recession period is reliable to express the aquifer response.

The stream flow recession curve effectively represents the relationship between storage and outflow. Every runoff components have their own characteristic of recession rates. However the ranges of the recession rates may overlap due to the unclear distinctions among surface flow-interflow-baseflow characteristics (Smatkin, 2001). Furthermore, Malik (2012) stated that several laminar and turbulent sub-regimes possibly exist in one aquifer (Fig. 3). The discharge from such combined system can be described by superposition of several equations. An example of flow regime separation and karstification degree calculation expressed in figure 4 below:

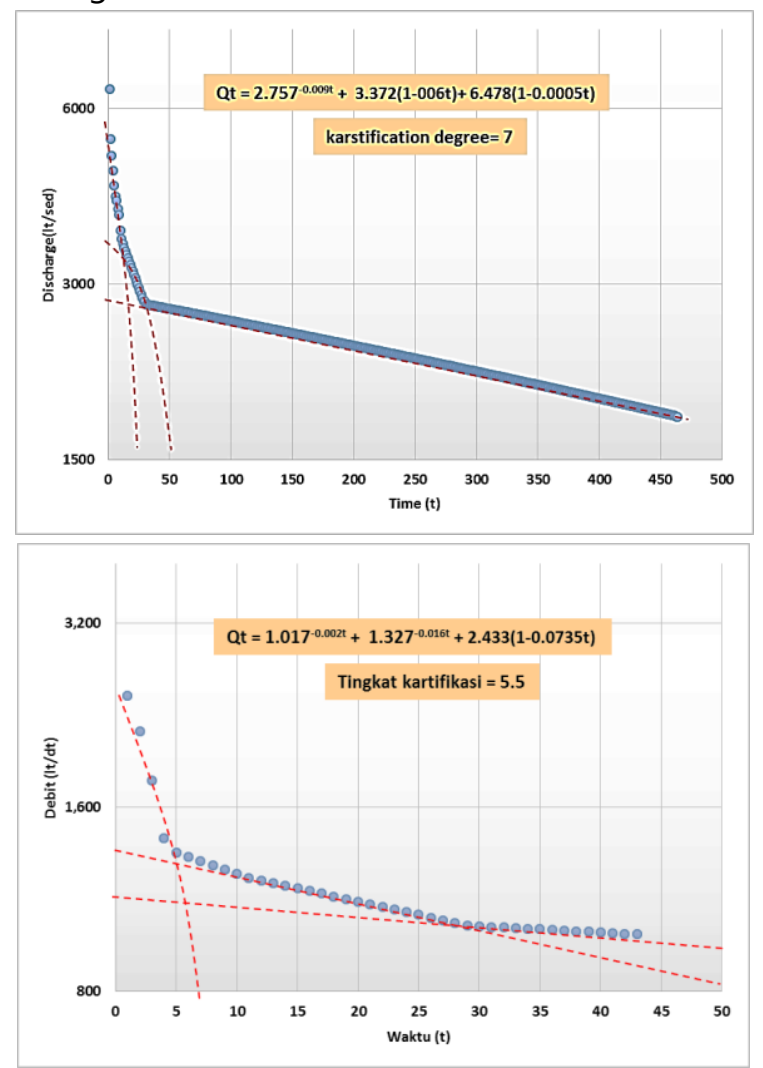

Figure 4. Determination of karstification degree based on flow regimes separation

Karstification degree is a quantified number that scientifically reliable to assess the condition of karst aquifer development. However, for karst river basin management, especially focused on water resources management, further analysis also required. In this case, hydrograph separation might be useful. Hydrograph separation into flow components is necessary to distinguish the proportions of individual flow component that present in total discharge. The main benefit of separating flow components is to estimate the quickflow duration and securing exploitable amount of karst water resources for longer periods. 
Based on hydrograph separation, the proportions of individual flow components that present in every stage of total discharge can be quantified (Malik, 2015).

Before separate the flow components from total discharge, calculations of individual flow volumes must be performed (Equation 4). Hydrograph separation can be performed either manually or automatically. Eckhardt (2005) introduced aoutomatic technique for hydrograph separation using digital filtering method. Separation of total discharge into two components, baseflow and direct runoff perfored using recursive digital filtering as expressed in Eq.5:

$$
y_{k}=b_{k}+f_{k}
$$

Where:

$$
\begin{aligned}
& y=\text { total discharge } \\
& b=\text { baseflow } \\
& f=\text { direct runoff } \\
& k=\text { time step number }
\end{aligned}
$$

The general form of a one-parameter filter whose parameter a corresponds to the groundwater recession constant is:

$$
b_{k}=\frac{\left(1-B F I_{\text {max }}\right) a q_{b(i-1)}+(1-a) B F I_{\max } q i}{1-a B F I_{\max }}
$$

This filter parameter describes baseflow recession function that expressed as an exponential equation, indicating recession periods without groundwater recharge. BFImax value that based on preliminary results have been suggested to minimize the subjective influence as follows:

- $B F I m a x=0.80$ for perennial streams with porous aquifers;

- $B F I m a x=0.50$ for ephemeral streams with porous aquifers;

- BFImax $=0.25$ for perennial streams with hard rock aquifers.

The example of calculated baseflow component shown in figure 5 below:

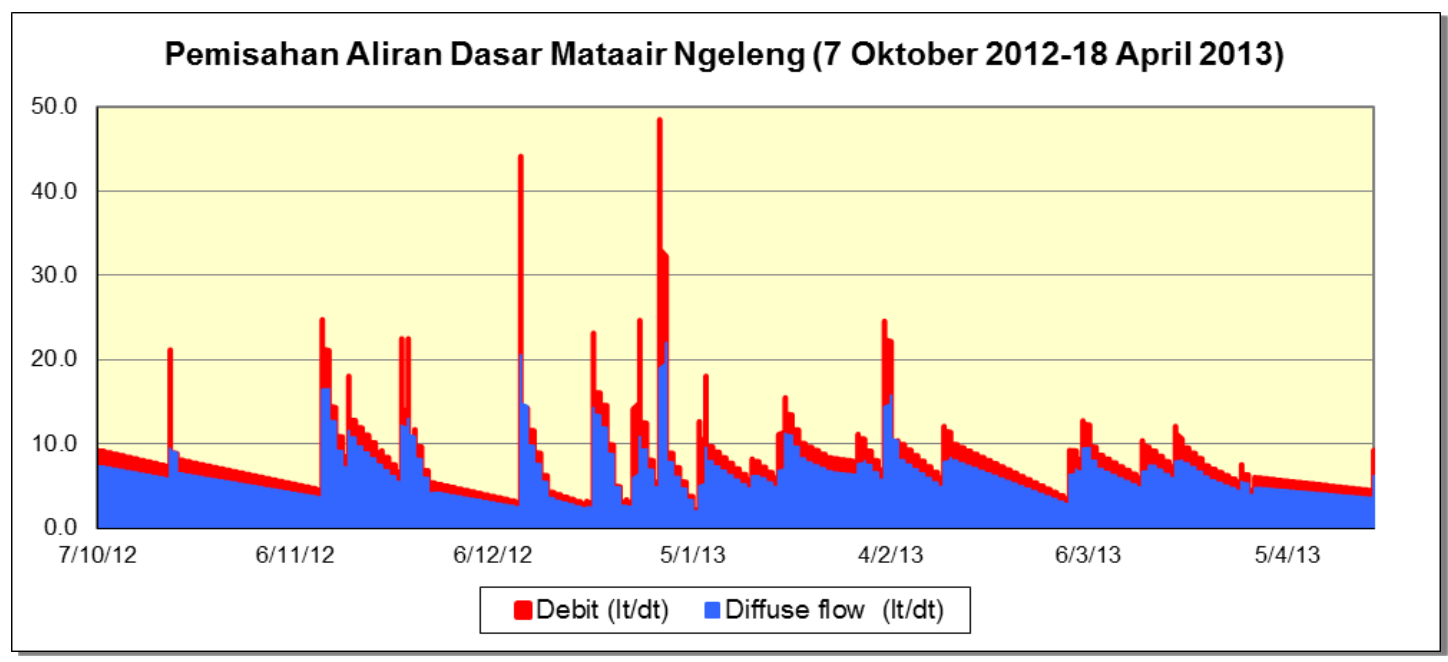

Figure 5. Baseflow separation method 


\section{CONCLUSION}

Recession curve analysis provides useful information to interpret the hydrological significance and characterize specific parameters of the springs. The main advantage of analysing spring recession curves is that the drainage mechanisms in the aquifer and its quantitative parameters will be able to be estimated. The construction MRC is necessary in order to combine several individual recessions to provide an average characterization of baseflow response. Furtermore, the main benefit of separating flow components is to estimate the quick-flow duration and securing exploitable amount of karst water resources for longer periods. This is necessary to secure karst water resources from over exploitation.

\section{ACKNOWLEDGEMENT}

This research paper was successfully presented by funding from Hibah Penelitian Unggulan Perguruan Tinggi (PUPT) Kementerian Pendidikan Tinggi. The author wishes to fully express his profound gratitude to Dr. Tjahyo Nugroho Adji, M.Sc.Tech for his support and guidance for the author.

\section{REFERENCES}

Amit, H., Lyakhovsky, V., Katz, A., Strasinsky, A., \& Burg, A. (2002). Interpretation of Spring Recession Curves. Groundwater vol 40 no 5, 543-551.

Bögli, A. (1980). Karst Hydrology and Physical Speleology. Berlin: Springer-Verlag.

Bonacci, O. (1993). Karst spring hydrograps as indicators of karst aquifers. Hydrological Sciences-Journal-des Sciences Hydrologiques 38,1,2, 51-62.

Eckhardt, K. (2005). How to construct recursive digitalfilters for baseflow separation. Hydrol. Process. 19, 507- 515.

Fatchurohman, H., \& Adji, T. N. (2014). Study of water-rock interactions to characterize karst aquifer in Ngeleng Spring. Indonesian-Japan Join Scientific Symposium (pp. 91-100). Yogyakarta: IJJSS.

Fiorillo, F. (2014). The Recession of Spring Hydrographs, Focused on Karst Aquifers. Water Resource Management, 1781-1805.

Fitts, C. R. (2002). Groundwater Science. London: Academic Press.

Ford, D., \& Williams, P. (2007). Karst Hydrology and Geomorphology. West Sussex: John Wiley \& Sons Ltd.

Gillieson, D. (1996). Caves : Processes, Development andManagemant. Oxford: Blackwell Publisers.

Kresic, N. (2013). Water in Karst ; Management, Vulnerability, and Restoration. New York: McGraw-Hill.

Malik, P. (2007). Assessment of regional karstification degree and groundwater sensitivity to pollution using hydrograph analysis in the Velka Fatra Mountains, Slovakia. Environ Geol vol.51, 707-711.

Malik, P. (2015). Evaluating Discharge Regimes of Karst Aquifers. In Z. Stevanovic', Karst Aquifers - Characterization and Engineering (pp. 205-249). -: Springer International Publishing Switzerland.

Malik, P., \& Vojtkova, S. (2012). Use of recession-curve analysis for estimation of karstification degree and its application in assessing overflow/underflow conditions in closely spaced karstic springs . Environ Earth Sci (2012) 65, 2245-2257. 
Nathan, R., \& McMahon, T. (1990). Evaluation of Automated Techniques for Base Flow and Recessions Analysis. Water Resources Research vol. 26 no.7, 1465-1473.

Posavec, K., Parlov, J., \& Nakic, Z. (2010). Fully Automated Objective-Based Method for Master Recession Curve Separation. Groundwater Vol 48. No.4, 598-603.

Rashed, K. A. (2012). Assessing degree of karstification : a new method of classifying karst aquifers. Sixteenth International Water Technology Conference (pp. 1-9). Istanbul: IWTC.

Rivera-Ramírez, H. D., Warner, G., \& Scatena, F. (2002). Prediction of master recession curves and baseflow recessions in the luquillo mountains of puerto rico. American Water Resources Assosiation vol.38 no.3, 993-704.

Smatkin, V. (2001). Low flow hydrology: a review. Journal of Hydrology 240, 147-186.

Tallaksen, L. (1995). A review of baseflow recession analysis . Journal of Hydrology 165 , 349370 .

Todd, D. K., \& Mays, L. W. (2005). Groundwater Hydrology-Third Edition. New York: John Wiley \& Sons.

UNICEF, \& WHO. (2015). 25 Years Progress on Sanitation and Drinking Water-2015 Update and MDG Assessment. Geneva: WHO Press.

Walton, W. C. (1970). Groundwater Resource Evaluation. Tokyo: McGraw-Hill.

Widyastui, M. (2014). Kajian Kerentanan Airtanah Terhadap Pencemaran di Daerah Karst Gunung Sewu (Studi di Daerah Aliran Sungai Bawah Tanah Bribin Kabupaten Gunungkidul dan Wonogiri). Dissertation. Yogyakarta: Faculty of Geography.

Younger, P. L. (2007). Groundwater in The Environment. Victoria: Blackwell Publishing. 